\section{Evaluation of radiological anatomy knowledge among dental students}

\section{Diş hekimliği öğrencilerinin radyoanatomi bilgilerinin değerlendirilmesi}

\section{Prof. Dilhan ilgüy}

Yeditepe University, Faculty of Dentistry Department of Dentomaxillofacial Radiology, Istanbul

\section{Prof. Mehmet ilgüy}

Okan University, Faculty of Dentistry, Department of Dentomaxillofacial Radiology, Istanbul

\section{Assoc. Prof. Zehra Semanur Dölekoğlu}

Yeditepe University, Faculty of Dentistry Department of Dentomaxillofacial Radiology, Istanbul

\section{Assist. Prof. Nilüfer Ersan}

Yeditepe University, Faculty of Dentistry Department of Dentomaxillofacial Radiology, Istanbul

\section{Assoc. Prof. Erdoğan Fişekçioğlu}

Yeditepe University, Faculty of Dentistry Department of Dentomaxillofacial Radiology, Istanbul

Received: 31 March 2017

Accepted: 17 May 2017

doi: 10.5505/yeditepe.2017.49140

\section{Corresponding author:}

Assist. Prof. Nilüfer Ersan Yeditepe University, Faculty of Dentistry, Department of Dentomaxillofacial Radiology, Bağdat Cad. No: 238/3/A 34728 Göztepe İstanbul / Türkiye Tel: +90 2163636044 / 6414

E-mail: nilufer.ersan@yeditepe.edu.tr

\section{SUMMARY}

Aim: The dentists should identify the normal anatomic structures on dental radiographs and know about image distortion characteristics of technical errors and projection artifacts. Strategies must be developed by authorities in order to implement this attitude into regular curriculum of dental faculties. Assessment of the learning outcomes of dental students may give information to help dental educators improve their curriculum. The aim of this study was to assess the retention of knowledge of dental students on the panoramic and periapical radiographs.

Materials and Method: Undergraduate students from the third up to the fifth year $(n=129)$ and postgraduate students $(n=23)$ took part in the study. The test consisted of 10 questions accompanied by 10 periapical radiographs that demonstrated labeled anatomical structures, and 5 panoramic radiographs consisting of 26 anatomical structures with one or more labels. For the postgraduate students, 12 patient positioning errors, 3 foreign body detection and 4 technical errors were additionally questioned.

Results: A statistically significant correlation was found between the classes and the overall performance on anatomical knowledge, with the 3rd year students receiving the highest score $(90 \%, \mathrm{p}<0.01)$. Postgraduate students' ability to recognize panoramic film faults and foreign bodies correctly ranged from $5.26 \%$ to $63.16 \%$. The questions about the foreign body identification were answered with the highest percentage (eyeglasses $95.7 \%$; ghost image of earrings $91.3 \%$; tongue piercing $87 \%$ ).

Conclusions: Integration of dental radiology lecture to the fifth year curriculum may be helpful for the retention of knowledge of dental students on the panoramic and periapical radiographs.

Key words: Dental radiology education, anatomic landmarks, panoramic technique errors, periapical radiography.

\section{ÖZET}

Amaç: Diş hekimleri, dental radyografiler üzerindeki normal anatomik yapıları belirleyebilmeli ve teknik hatalara bağlı görüntü distorsiyonları ve artefaktları konusunda bilgi sahibi olmalıdır. Diş hekimliği öğrencilerinin öğrenme çıktılarının değerlendirilmesi müfredatın geliştirilmesi için eğitimcilere bilgi sağlayabilmektedir. Bu çalıșmada diş hekimliği öğrencilerinin panoramik ve periapikal radyografilerle ilgili bilgilerinin değerlendirilmesi amaçlanmıştır.

Gereç ve Yöntem: Diş hekimliği 3., 4. ve 5. sınıf öğrencileri $(n=129)$ ile yüksek lisans öğrencilerinin $(n=23)$ yer aldığı bu çalışmada 10 farklı anatomik yapının işaretlendiği 10 adet periapikal radyografi ve 26 farklı anatomik yapının işaretlendiği 5 adet panoramik radyografi kullanıımıştır. Ayrıca yüksek lisans öğrencileri için 12 hasta konumlandırma hatası, 3 yabancı cisim varlığı ve 4 teknik hata gözlenen panoramik radyografiler çalışmaya dahil edilmiştir. 
Bulgular: Anatomik bilgi düzeyi konusunda sınıflar arasında istatistik açıdan anlamlı farklar gözlenmiş, 3. sınıf öğrencileri en yüksek skoru elde etmişlerdir (\%90; $p<0.01)$. Yüksek lisans öğrencilerinin panoramik film hatalarını ve yabancı cisimleri doğru bir şekilde belirleme konusundaki başarı yüzdesi \%5,26 ile \%63,16 arasında değişmektedir. Yabancı cisim belirlenmesi konusundaki sorular en yüksek yüzdeyle cevaplanmıştır (gözlük: \%95.7; küpe: \%91.3; dil hızması \%87).

Sonuçlar: Dental radyoloji eğitiminin 5. sınıf müfredatına entegre edilmesinin, diş hekimliği öğrencilerinin panoramik ve periapikal radyografilerle ilgili bilgilerinin daha kalıcı olmasına yardımcı olabileceği düşünülmektedir.

Anahtar Kelimeler: Diş hekimliği eğitimi, anatomik noktalar, panoramik radyografi hataları, periapikal radyografi.

\section{INTRODUCTION}

Periapical radiography is an intraoral imaging technique that gives thorough information about the teeth and the adjacent hard tissues. Since the jaws, especially the maxillary bone has a complex anatomy, ideal positioning cannot be provided in all patients. Even though all the requirements for the positioning the film were met, some anatomical structures might be confused with periapical radiolucencies.

Panoramic radiography, which is an extraoral technique, is a routine imaging method in dental practice and is an important diagnostic tool in dentistry. Panoramic image is a complex projection of the oral cavity resulting in various superimpositions and distortions which may be aggravated by technical errors during image processing. Moreover, the panoramic radiography illustrates several anatomical structures other than the jaws, which may generate further interpretation difficulties. Panoramic images are difficult to interpret as a number of superimposing images may be observed, such as soft-tissue shadows, air spaces, ghost images and double images. In addition, different panoramic devices may also cause differences in the appearance of these images due to the individual technical properties of each device and it is necessary to have knowledge about the features of the machine..$^{1,2}$

The Commission on Dental Accreditation states that "Graduates must be competent in interpreting diagnostic periapical, and panoramic radiographs". ${ }^{3}$ Several other dental organizations have also made suggestions regarding the quality and the interpretation of the radiographic image. ${ }^{4-6}$ Dental practitioners should receive training with theoretical knowledge and practical experience, in diagnostic radiology as relevant to the specific area of practice. ${ }^{7}$ After dental radiology education, a student should know how the panoramic and periapical radiography is formed and assess the accurateness of the image. The graduates should know about image distortion characteristics of technical errors and projection artifacts and be able to distinguish these distortions in interpreting radiographs. The normal anatomic structures must also be identified on a panoramic image to diagnose any abnormalities correctly. ${ }^{8}$ Strategies must be developed by authorities in order to implement this attitude into regular curriculum. In our faculty, the educational committee comes together once a week to improve the curriculum to be compatible with the universal standards. Improving students' capability in radiographic aspects of dentistry must be one of the priority tasks of the committee. Assessment of the learning outcomes, may give information to help dental educators improve their curriculum.

To the best of our knowledge there are no previous studies evaluating the retention of knowledge regarding radiographic landmarks and comparing the knowledge on these landmarks according to the grade of the dental students. Thus, the aim of this study was to evaluate the retention of knowledge of undergraduate and postgraduate students on the anatomical landmarks on panoramic and periapical radiographies as a part of the assessment of learning outcome.

\section{MATERIAL AND METHODS}

The study has received formal review and approval by the institutional review board of the faculty. There was no necessity to make a power calculation because the study was conducted on all students enrolled in each class with $100 \%$ participation. Undergraduate students from the third up to the fifth year $(n=129)$ of a 5-year dental curriculum and postgraduate students $(n=23)$ from academic years 2011-2012 took part in the study. The study was performed at the end of the academic year for the third year students, whereas at the beginning of the academic year for the rest of the students. The radiographs which were considered to have a good quality were projected as PowerPoint presentation (Microsoft Corp, Redmond, WA) in a darkened classroom on barcovision and three monitors. An answer sheet was given to each student. Students were allowed 5 minutes to evaluate each film. At the end of the slide show, a quick re-viewing was made for the slides which they wanted to see again.

For the undergraduate students, the test included only the anatomical landmarks which consisted of 10 questions accompanied by periapical radiographs that demonstrated 10 anatomical structures (Table 1) and 5 panoramic radiographs with 26 anatomical structure(s), one or more labeled with numbered arrows (Table 2).

For the postgraduate students, not including the students at the dentomaxillofacial radiology department, in addition to the anatomical landmarks a second part, including 12 questions on patient positioning error(s) 
recognition, 3 questions on foreign body detection and also 4 questions on technical error identification on panoramic radiographs, were added to the test, considering their specific curriculum which differed from that of the undergraduates. At the beginning of the second part, postgraduate students were informed that a number of the films revealed some film faults and were asked to find and name these faults (Table 3 ).

Table 1. Evaluation of periapical anatomy knowledge according to the grade of the students.

\begin{tabular}{|c|c|c|c|c|c|}
\hline $\begin{array}{l}\text { Anatomical } \\
\text { landmarks }\end{array}$ & $\begin{array}{c}\text { 3rd grade } \\
\text { n (\%) }\end{array}$ & $\begin{array}{c}\text { 4th grade } \\
\text { n (\%) }\end{array}$ & $\begin{array}{c}\text { 5th grade } \\
\text { n (\%) }\end{array}$ & $\begin{array}{c}\text { Post grad. } \\
\text { n (\%) }\end{array}$ & $p$ \\
\hline 1. Incisive foramen & $38(\% 100.0)$ & $38(\% 82.6)$ & $\begin{array}{l}40 \\
(\% 88.9)\end{array}$ & $21(\% 91.3)$ & 0.066 \\
\hline $\begin{array}{l}\text { 2. Median palatine } \\
\text { suture }\end{array}$ & $38(\% 100.0)$ & $45(\% 97.8)$ & $\begin{array}{l}42 \\
(\% 93.3)\end{array}$ & $20(\% 87.0)$ & 0.085 \\
\hline 3. Soft tissue of the nose & $25(\% 65.8)$ & $21(\% 45.7)$ & $\begin{array}{l}14 \\
(\% 31.1)\end{array}$ & $12(\% 52.2)$ & $0.017^{*}$ \\
\hline 4. Lateral fossa & $22(\% 57.9)$ & $10(\% 21.7)$ & $1(\% 2.2)$ & $13(\% 56.5)$ & $0.001^{* * *}$ \\
\hline 5. Coronoid process & $38(\% 100.0)$ & $7(\% 15.2)$ & $6(\% 13.3)$ & $16(\% 69.6)$ & $0.001 * *$ \\
\hline 6. Mental ridge & $37(\% 97.4)$ & $28(\% 60.9)$ & $0(\% 0.0)$ & $18(\% 78.3)$ & $0.001 * *$ \\
\hline 7. Lingual foramen & $36(\% 94.7)$ & $43(\% 93.5)$ & $1(\% 2.2)$ & $17(\% 73.9)$ & $0.001 * *$ \\
\hline 8. Mylohyoid ridge & $37(\% 97.4)$ & $25(\% 54.3)$ & $0(\% 0.0)$ & $16(\% 69.6)$ & $0.001 * *$ \\
\hline 9. Mandibular canal & $37(\% 97.4)$ & $42(\% 91.3)$ & $\begin{array}{l}44 \\
(\% 97.8)\end{array}$ & $\begin{array}{l}23 \\
(\% 100.0)\end{array}$ & 0.240 \\
\hline 10. Mental foramen & $35(\% 92.1)$ & $38(\% 82.6)$ & $\begin{array}{l}42 \\
(\% 93.3)\end{array}$ & $18(\% 78.3)$ & 0.176 \\
\hline
\end{tabular}

Table 2. The percentage of correct answers to anatomical landmarks on pan oramic radiographs according to student's grade.

\begin{tabular}{|c|c|c|c|c|c|}
\hline & 3rd grade & 4th grade & 5th grade & Post graduate & \multirow[t]{2}{*}{$p$} \\
\hline & n (\%) & n (\%) & n (\%) & n (\%) & \\
\hline Zygomatic arch & $20(\% 52.6)$ & $22(\% 47.8)$ & $0(\% 0.0)$ & $6(\% 26.1)$ & $0.001 * *$ \\
\hline Articular eminence & $12(\% 31.6)$ & $0(\% 0.0)$ & $0(\% 0.0)$ & $11(\% 47.8)$ & $0.001 * *$ \\
\hline External auditory meatus & $23(\% 60.5)$ & $33(\% 71.7)$ & $20(\% 44.4)$ & $6(\% 26.1)$ & $0.002 * *$ \\
\hline Infraorbital ridge & $25(\% 65.8)$ & $30(\% 65.2)$ & $37(\% 82.2)$ & $17(\% 73.9)$ & 0.249 \\
\hline Nasal septum & $35(\% 92.1)$ & $33(\% 71.7)$ & $35(\% 77.8)$ & $21(\% 91.3)$ & 0.055 \\
\hline Inferior nasal concha & $34(\% 89.5)$ & $28(\% 60.9)$ & $28(\% 62.2)$ & $19(\% 82.6)$ & $0.008^{* *}$ \\
\hline Cervical vertebrae & $25(\% 65.8)$ & $31(\% 67.4)$ & $34(\% 75.6)$ & $12(\% 52.2)$ & 0.283 \\
\hline Mental foramen & $35(\% 92.1)$ & $35(\% 76.1)$ & $41(\% 91.1)$ & $20(\% 87.0)$ & 0.112 \\
\hline Hyoid bone & $34(\% 89.5)$ & $38(\% 82.6)$ & $37(\% 82.2)$ & $20(\% 87.0)$ & 0.769 \\
\hline Hard palate & $29(\% 76.3)$ & $36(\% 78.3)$ & $4(\% 8.9)$ & $17(\% 73.9)$ & $0.001^{* * *}$ \\
\hline Mandibular canal & $37(\% 97.4)$ & $40(\% 87.0)$ & $20(\% 44.4)$ & $20(\% 87.0)$ & $0.001^{* * *}$ \\
\hline Tongue & $34(\% 89.5)$ & $0(\% 0.0)$ & $1(\% 2.2)$ & $10(\% 43.5)$ & $0.001^{* *}$ \\
\hline Soft palate & $28(\% 73.7)$ & $30(\% 65.2)$ & $0(\% 0.0)$ & $7(\% 30.4)$ & $0.001 * *$ \\
\hline Uvula & $19(\% 50.0)$ & $2(\% 4.3)$ & $0(\% 0.0)$ & $4(\% 17.4)$ & $0.001 * * *$ \\
\hline Posterior pharyngeal wall & $24(\% 63.2)$ & $15(\% 32.6)$ & $0(\% 0.0)$ & $1(\% 4.3)$ & $0.001 * *$ \\
\hline Ear lobe & $19(\% 50.0)$ & $27(\% 58.7)$ & $5(\% 11.1)$ & $9(\% 39.1)$ & $0.001 * *$ \\
\hline Glossopharyngeal air space & $14(\% 36.8)$ & $26(\% 56.5)$ & $0(\% 0.0)$ & $1(\% 4.3)$ & 0.001 ** \\
\hline Nasopharyngeal air space & $23(\% 60.5)$ & $11(\% 23.9)$ & $0(\% 0.0)$ & $1(\% 4.3)$ & 0.001 ** \\
\hline Maxillary sinus & $15(\% 39.5)$ & $12(\% 26.1)$ & $0(\% 0.0)$ & $14(\% 60.9)$ & 0.001 ** \\
\hline Styloid process & $6(\% 15.8)$ & $0(\% 0.0)$ & $0(\% 0.0)$ & $0(\% 0.0)$ & $0.001 * *$ \\
\hline Coronoid process & $18(\% 47.4)$ & $6(\% 13.0)$ & $1(\% 2.2)$ & $15(\% 65.2)$ & $0.001 * *$ \\
\hline Mandibular canal & $38(\% 100.0)$ & $40(\% 87.0)$ & $20(\% 44.4)$ & $20(\% 87.0)$ & 0.001 ** \\
\hline Nasal fossa & $33(\% 86.8)$ & $24(\% 52.2)$ & $9(\% 20.0)$ & $9(\% 39.1)$ & 0.001 ** \\
\hline Nasal septum & $36(\% 94.7)$ & $34(\% 73.9)$ & $30(\% 66.7)$ & $21(\% 91.3)$ & $0.005^{* *}$ \\
\hline Anterior nasal spine & $28(\% 73.7)$ & $21(\% 45.7)$ & $13(\% 28.9)$ & $18(\% 78.3)$ & $0.001 * *$ \\
\hline Condyle & $36(\% 94.7)$ & $20(\% 43.5)$ & $34(\% 75.6)$ & $15(\% 65.2)$ & $0.001 * *$ \\
\hline
\end{tabular}

SPSS (Statistical Package for Social Sciences) for Windows 15.0 software package (IBM, New York, USA) was used for the statistical analysis in the evaluation of the results. During the evaluation of the study data, along with the descriptive statistical methods, parameters were evaluated using Kruskall Wallis analysis, Mann Whitney U-test and Chi-square test. Significance was accepted at $p<0.05$ level.

Table 3. Correct answer rates of postgraduate students for the second part of the test.

\begin{tabular}{|l|c|c|}
\hline $\begin{array}{l}\text { 1. The anterior teeth are positioned behind the notch in } \\
\text { the bitestick }\end{array}$ & n & 3 \\
\hline 2. Chin tipped/tilted too low & 8 & 13.0 \\
\hline 3. Head twisted/turned & 11 & 34.8 \\
\hline 4. Chin tipped/tilted too high & 6 & 47.8 \\
\hline 5. Patient too far forward & 7 & 26.1 \\
\hline 6. Patient too far back & - & 30.4 \\
\hline 7. Chin tipped down & 6 & - \\
\hline 8. Chin up too high & 3 & 26.1 \\
\hline 9. Head twisted & 14 & 13.0 \\
\hline 10. 'Slumped' patient position & - & 60.9 \\
\hline 11. Tongue down during exposure & 9 & - \\
\hline 12. Patient movement & 10 & 39.1 \\
\hline 13. Eyeglasses & 22 & 43.5 \\
\hline 14. Tongue piercing & 20 & 95.7 \\
\hline 15. Ghost image of earrings & 21 & 87.0 \\
\hline 16. Static electricity & 6 & 91.3 \\
\hline 17. Double exposure & - & 26.1 \\
\hline 18. Underexposure & 2 & - \\
\hline 19. Lead apron artifact & 5 & 8.7 \\
\hline
\end{tabular}

Table 4. Success rates of the students according to their grades

\begin{tabular}{|c|c|c|c|c|c|}
\hline & $3^{\text {rd }}$ year & $4^{\text {th }}$ year & $5^{\text {th }}$ year & Post grad & $p$ \\
\hline & Mean \pm SD(M) & $\operatorname{Mean} \pm \mathbf{S D}(\mathbf{M})$ & Mean \pm SD(M) & Mean \pm SD(M) & \\
\hline Periapical & $\begin{array}{c}90.26 \pm 9.15 \\
(90)\end{array}$ & $\begin{array}{c}64.56 \pm 18.22 \\
(70)\end{array}$ & $\begin{array}{c}42.22 \pm 7.94 \\
(40)\end{array}$ & $\begin{array}{c}75.65 \pm 17.27 \\
(80)\end{array}$ & $0.001 *$ \\
\hline Panoramic & $\begin{array}{c}61.40 \pm 20.92 \\
(52.38)\end{array}$ & $\begin{array}{c}44.30 \pm 18.92 \\
(47.62)\end{array}$ & $\begin{array}{c}24.97 \pm 11.18 \\
(23.81)\end{array}$ & $\begin{array}{c}44.41 \pm 16.12 \\
\quad(40.48)\end{array}$ & $0.001 *$ \\
\hline Overall & $\begin{array}{c}66.95 \pm 17.20 \\
(59.62)\end{array}$ & $\begin{array}{c}48.20 \pm 17.66 \\
(50.96)\end{array}$ & $\begin{array}{c}28.29 \pm 9.52 \\
(26.92)\end{array}$ & $\begin{array}{c}50.42 \pm 15.64 \\
(48.1)\end{array}$ & $0.001 *$ \\
\hline
\end{tabular}

\section{RESULTS}

The study sample consisted of 38 (25\%) third year, 46 (30.3\%) fourth year, 45 (29.6\%) fifth year and $23(15.1 \%)$ postgraduate students. The percentages of correct responses to the questions of periapical and panoramic radiographic anatomy according to grades are shown in Table 1 and 2.

Most of the students could not define lateral fossa on periapical radiography and the senior year students had the lowest score with $2.2 \%(p<0.001)$. Also the questions about mental ridge, lingual foramen, mylohyoid ridge were answered unsuccessfully by senior year students (Table 1, 0.0\%, 2.2\%, and $0.0 \%$ respectively, $\mathrm{p}<0.0 \mathrm{l}$ ). Among all the questions of panoramic radiography, the percentages of correct responses to the question about the styloid process were the lowest as shown in Table 2. The mean success percentages of 3rd, 4th, senior year, and postgraduate students in identifying anatomical landmarks on radiographs were $66.9 \% \pm 17.2 \%, 48.2 \% \pm 17.7 \%$, $28.3 \% \pm 9.5 \%$ and $50.4 \% \pm 15.6 \%$, respectively according to Kruskal Wallis test $(p<0.0 l)$ (Table 4). A statistically significant correlation was found between the class levels and the overall performance on anatomical knowledge, with 
the $3 r d$ year students receiving the highest score $(p<0.0 l)$ (Table 4). For both periapical and panoramic radiographic anatomy, there were statistically significant differences between the students. While 3rd year students had the highest performance, the senior year students had the lowest $(p<0.0 l)$ (Table 5).

\begin{tabular}{|c|c|c|c|c|c|}
\hline & $3^{\text {rd }}$ year & $4^{\text {th }}$ year & $5^{\text {th }}$ year & Post grad & $p$ \\
\hline & Mean $\pm \mathrm{SD}(\mathrm{M})$ & Mean $\pm \mathrm{SD}(\mathrm{M})$ & Mean $\pm \mathrm{SD}(M)$ & Mean \pm SD(M) & \\
\hline Periapical & $\begin{array}{c}90.26 \pm 9.15 \\
(90)\end{array}$ & $\begin{array}{c}64.56 \pm 18.22 \\
(70)\end{array}$ & $\begin{array}{c}42.22 \pm 7.94 \\
(40)\end{array}$ & $\begin{array}{c}75.65 \pm 17.27 \\
(80)\end{array}$ & 0.001 * \\
\hline Panoramic & $\begin{array}{c}61.40 \pm 20.92 \\
(52.38)\end{array}$ & $\begin{array}{c}44.30 \pm 18.92 \\
(47.62)\end{array}$ & $\begin{array}{c}24.97 \pm 11.18 \\
(23,81)\end{array}$ & $\begin{array}{c}44.41 \pm 16.12 \\
(40.48)\end{array}$ & $0.001 *$ \\
\hline Overall & $\begin{array}{c}66.95 \pm 17.20 \\
(59.62)\end{array}$ & $\begin{array}{c}48.20 \pm 17.66 \\
(50.96)\end{array}$ & $\begin{array}{c}28.29 \pm 9.52 \\
(26.92)\end{array}$ & $\begin{array}{c}50.42 \pm 15.64 \\
(48.1)\end{array}$ & $0.001^{*}$ \\
\hline
\end{tabular}

Table 5. Results of periapical and panoramic radioanatomy knowledge.

\begin{tabular}{|c|c|c|c|c|c|c|}
\hline & $\begin{array}{c}3 \mathrm{rd} / \\
\text { 4th grad. }\end{array}$ & $\begin{array}{c}\text { 3rd } / \\
\text { 5th grad. }\end{array}$ & $\begin{array}{c}\text { 3rd / } \\
\text { Postgrad. }\end{array}$ & $\begin{array}{c}\text { 4th } / \\
\text { 5th grad. }\end{array}$ & $\begin{array}{c}\text { 4th / } \\
\text { Postgrad. }\end{array}$ & $\begin{array}{c}\text { 5th / } \\
\text { Postgrad. }\end{array}$ \\
\hline & p & $\mathbf{p}$ & $\mathbf{p}$ & $\mathbf{p}$ & p & $\mathbf{p}$ \\
\hline Periapical & $0.001 * *$ & $0.001 * *$ & $0.001^{* *}$ & $0.001 * *$ & $0.043^{*}$ & $0.001^{* *}$ \\
\hline Panoramic & $0.002^{* * *}$ & $0.001^{* *}$ & $0.002^{* *}$ & 0.001 ** & 0.779 & 0.001 ** \\
\hline verall & $0.001 * *$ & $0.001 * *$ & $0.001 * *$ & 0.001 ** & 0.799 & $0.001^{* *}$ \\
\hline
\end{tabular}

Table 3 shows the second part (includes patient positioning error, foreign body detection, and technical errors) of the test which was answered by only postgraduate students. Their ability to recognize panoramic film faults and foreign bodies correctly ranged from $5.3 \%$ to $63.16 \%$. The questions about the foreign body identification were answered with the highest percentage (eyeglasses 95.7\%; ghost image of earrings $91.3 \%$; tongue piercing $87 \%$ ). The mean success percentage of postgraduate students was found as $35.5 \% \pm 15.8 \%$ with a median value of $31.6 \%$. The questions about the issues related to "double exposure", "slumped positioning" and "the patient being too far back" were not answered correctly by the students. According to the results, it is clear that undergraduate students showed a decreasing success while the class levels increased for identifying anatomical landmarks (Table 4).

\section{DISCUSSION}

In this study evaluating the retention of knowledge of undergraduate and postgraduate dental students regarding periapical and panoramic anatomical landmarks and comparing their knowledge according to the grade of the students for the first time, the mean success percentage of 3rd year students was found to be the highest. This finding might suggest that the students are more successful on the information obtained recently. Even though it could be speculated that in addition to the theoretical information obtained priorly, the experience gained by dental practice over the time leads to a better knowledge on anatomical landmarks. Unfortunately, it seems that the main concentration of dental students in interpreting dental radiographs had been the region of interest, which is mostly the dental pathologies. Sometimes, apart from required information on dental pathologies, incidental findings, i.e. carotid artery calcification, odontogenic or nonodontogenic cysts, elongated styloid process, maxillary sinus pathologies, foreign bodies etc., do present on the radiographs. Identification and reporting of such findings is of critical importance because they may necessitate medical and/or dental intervention. Besides, identification of the findings and referring the patient to the relevant department is the responsibility of the dentists. Thus, a thorough evaluation of panoramic radiographs is needed in every patients.

For instance, none of the postgraduate students identified styloid process correctly on panoramic radiographs. It was previously reported that elongation of styloid process may be observed up to $30 \%$ of the population, and in most of these cases it is seen bilaterally, which may be misinterpreted as an anatomical structure. ${ }^{9}$ Eagle syndrome, which is characterized of a neck pain due to the elongation of styloid process because of a calcified stylohyoid ligament, might be regarded as an inexplicable clinical situation unless it could be identified on panoramic radiographs.

Panoramic image shows a much larger area of anatomic structures. For that reason, more time will be needed to evaluate these structures, however after many practices on observing the films, a dentist will be able to make a rapid assessment. It is important to have a thorough knowledge of the normal anatomy in order to define any abnormalities. It is helpful to assess one side in accordance with the other side of the image during making a decision whether a finding is normal or not, as structures appearing bilaterally are mostly anatomic. On the other hand, it should be borne in mind that, in some cases the two sides might be unequally magnified because of the positioning errors. ${ }^{10}$

Accurate analysis of panoramic radiographs starts with an understanding of the head and neck anatomy and how it is projected on these radiographs. A systematic thinking is necessary for the assessment of this image in that the practitioner must be careful in assessing all anatomic structures to make sure that they are normal. Having knowledge about the anatomic structures on a panoramic radiography as well as the many superimpositions and distortions will help the practitioner to be more successful on this procedure. ${ }^{11}$

Periapical radiographs demonstrate relatively smaller area of the dental arch. While interpreting periapical radiographs, anatomical structures like maxillary sinus, incisive foramen and mental foramen might be confused with periapical radiolucencies.

Some standards have previously been developed for undergraduate dentomaxillofacial radiology courses 
and these serve as guidelines describing the core curriculum. ${ }^{12-16}$ However; competency based education is currently being used instead of these modalities. Outcomes-based education is also one term that is used for competency-based education. ${ }^{7}$ National authorities and organizations of the United States ${ }^{4,5}$ and the United Kingdom $^{6}$ have specifically adopted this unique educational system. The expansion of the European Union has also necessitated the convergence of standards within all European network due to the associated directives. ${ }^{17-19}$ Within the framework of this educational model, it is the outcome of the dental education that should be focused on rather than the content. ${ }^{7}$ In competency-based education, the knowledge, skills and values a student is expected to possess upon graduation are clearly defined. This model includes competencies and abilities that a senior student is obliged to achieve accurately and effectively. These programs evaluate the necessary competencies from cognitive, the affective and psychomotor dimensions. There are specifically defined competency statements and learning outcomes that clearly express these abilities. Core competencies, key skills, baseline competencies, or instructional blueprints are among other terms that can be used instead. ${ }^{7}$ Kumar et al. ${ }^{20}$ reported on the redesign of a traditional lecture-based course into a caseand team-based, active learning format that emphasizes the development of students' clinical problem-solving and decision making skills. Upon graduation, a dentist must be capable of decision-making and judgment in order to develop a differential or definite diagnosis during interpretation of radiographs. The student must be familiar with the principles that underlie imaging modalities used in dentistry. ${ }^{4}$ Regarding dental radiology, there are standards expected of a dental student upon graduation. Razmus et al. ${ }^{8}$ reported that in general senior year dental students were competent in recognizing anatomic landmarks on panoramic radiographs $(87.8 \% \pm 12.6 \%)$. On the contrary, in the present study senior year students were generally incompetent in recognizing anatomic landmarks on radiographs, receiving the lowest score (the mean percentage of correct responses was $28.3 \% \pm 9.5 \%$ ). This discrepancy could be attributed to the possible differences between the curriculum among the faculties that our students received radiological education only in their third year of education. Besides, the 3rd year students were able to identify the anatomic landmarks on radiographs more successfully compared to their peers (periapical $90.3 \% \pm 9.1 \%$, panoramic $61.4 \% \pm 20.9 \%$ ).

Razmus et al. ${ }^{8}$ also found that success in performance in detecting the error and artifacts and error correction was relatively poor among the senior year dental undergraduates (mean percentage of correct responses was $61.7 \% \pm 23.2 \%$ and $45.2 \% \pm 31.2 \%$, respectively). Rushton et al. ${ }^{21}$ demonstrated the medians of identifying film faults to be $17(35 \%)$ and 21 (43\%) for two dental schools. In the present study, the second part of the test (including patient positioning error, foreign body detection and technical errors) was applied to only graduate students, and their performance in these areas was considerably poor (35.5\% $\pm 15.8 \%)$.

Postgraduate students were not capable of identifying anatomical landmarks and technical errors on panoramic radiographs, which was rather disappointing for dental practitioners who wish to specialize in a specific branch of dentistry. The reason for insufficient knowledge of these students in spite of receiving theoretical courses might be related to the lack of practical courses and different teaching methods of the universities they graduated. Since a thorough knowledge on anatomical landmarks is inevitable for the establishment of correct diagnosis, creation of an optimum treatment planning and performing a successful treatment, it is necessary to improve this knowledge by implementing the necessary revolutions in the undergraduate and postgraduate curriculum.

\section{CONCLUSION}

In order to improve the ability of the students to efficiently interpret periapical and panoramic radiographs, didactic and practical dental radiography lectures should be included in the curriculum of the 4th and senior year and postgraduate students. Problem based cases may be more interesting for students and group learning activities should be considered. These results imply that continuous repetition and updating of previously acquired information is essential for the retention of knowledge. Also, questioning of the knowledge on anatomic landmarks is recommended for the acceptance of the prospective students for postdoctorate education independently of the department. A follow-up study is being planned after implementing the necessary revisions to the curriculum.

\section{REFERENCES}

1.Monsour PA, Mendoza AR. Panoramic ghost images as an aid in the localization of soft tissue calcifications. Oral Surgery, Oral Medicine, Oral Pathology, Oral Radiology 1990; 69: 748-756.

2.Kaugars GE, Collet WK. Panoramic ghosts. Oral Surgery, Oral Medicine, Oral Pathology, Oral Radiology 1987; 63: 103-108.

3.ADA (American Dental Association), Commission on Dental Accreditation. Accreditation standards for dental education facilities. Chicago 1988; 16.

4.ADA (American Dental Association), Commission on Dental Accreditation, 1998.

Accreditation standards for dental education programs. Chicago, IL 1998; c1995-2007 
5.ADEA (American Dental Education Association). Competencies for the new dentist. Journal of Dental Education 2006; 70: 757-759.

6.FGDP (The Faculty of General Dental Practice). Key skills in primary dental care: the indispensible e-learning package. London, UK 2007.

7.IADMFR (International Association of Dentomaxillofacial Radiology) Education Standards Committee. Undergraduate dental education in dental and maxillofacial radiology. Dentomaxillofacial Radiology 2007; 36: 443-450. 8.Razmus TF, Williamson GF, Van Dis ML. Assessment of the knowledge of graduating American dental students about the panoramic image. Oral Surgery, Oral Medicine, Oral Pathology, Oral Radiology 1993; 76: 397-402.

9.Ersan N, ilgüy M, illgüy D. Eagle sendromu: olgu bildirimi. Acta Odontologica Turcica 2016; 33: 30-34

10.Venkatraman S, Gowda JS, Kamarthi N. Unusual ghost image in a panoramic radiograph. Dentomaxillofacial Radiology 2011; 40: 397-399.

11.Perschbacher S. Interpretation of panoramic radiographs. Australian Dental Journal 2012; 57: 40-45.

12.No authors listed. Undergraduate dental school curriculum: Dental radiology. Oral Surgery, Oral Medicine, Oral Pathology, Oral Radiology 1967; 24: 191-195.

13.Mourshed $F$. The undergraduate dental radiology curriculum. Journal of Dental Education 1979; 43: 680-682.

14.No authors listed. American Association of Dental Schools curricular guidelines for oral radiology. Journal of Dental Education 1980; 44: 674-679.

15. No authors listed. Curricular guidelines in postdoctoral oral radiology. Journal of Dental Education 1984; 48: 171-176.

16.No authors listed. Curriculum guidelines for predoctoral oral radiology. Journal of Dental Education 1987; 51: 254-259.

17.Shanley DB, Dowling PA, Claffey N, Nattestad A. European convergence towards higher standards in dental education: The DentEd Thematic Network Project. Medical Education 2002; 36: 186-192.

18.Plasschaert AJ, Holbrook WP, Delap E, Martinez C, Walmsley AD; Association for Dental Education in Europe. Profile and competences for the European dentist. European Journal of Dental Education 2005; 9: 98-107.

19.Plasschaert AJ, Lindh $C$, McLoughlin J, Manogue $M$, Murtomaa $\mathrm{H}$, Nattestad A, et al. Curriculum structure and the European Credit Transfer System for European dental schools: part I. European Journal of Dental Education 2006; 10: 123-130.

20.Kumar V, Gadbury-Amyot CC. A case-based and teambased learning model in oral and maxillofacial radiology. Journal of Dental Education 2012; 76: 330-337.

21.Rushton VE, Hirschmann PN, Bearn DR. The effectiveness of undergraduate teaching of the identification of radiographic film faults. Dentomaxillofacial Radiology 2005; 34: 337-342. 